\title{
Effect of plant spacing and fertility level on leaf area variation at different phenological stages of cape gooseberry (Physalis peruviana L.) grown in sodic soil
}

\author{
Angrej Ali ${ }^{*}$ and B. P. Singh ${ }^{2}$ \\ ${ }^{1}$ Faculty of Agriculture, Sher-e-Kashmir University of Agricultural Sciences and Technology of Kashmir, Wadura \\ Campus, Sopore-193201 (J\&K), INDIA \\ ${ }^{2}$ Department of Horticulture, Narendra Dev University of Agriculture and Technology, Kumarganj, Faizabad - 224229 \\ (UP), INDIA \\ *Corresponding author. E-mail: anghort@gmail.com \\ Received: January 28, 2016; Revised received: October 26, 2016; Accepted: January 26, 2017

\begin{abstract}
Vegetative and reproductive growth in cape gooseberry (Physalis peruviana L.) proceed concomitantly during the greater part of the life cycle thereby foliar traits (e.g. leaf area) become important in photosynthetic action of the plant. In present study, the leaf area variation in cape gooseberry was studied at five phenological stages i.e. pre-flowering (30 DAT), start of flowering (60 DAT), early fruiting (120 DAT), peak fruiting (180 DAT) and late fruiting (240 DAT), grown at three spacings $(60 \times 75,75 \times 75$ and $75 \times 90 \mathrm{~cm})$ and four NPK levels (control, 60:40:40, $80: 60: 60$ and 100:80:80 $\left.\mathrm{kg} \mathrm{ha}^{-1}\right)$. Leaf area increased from per-flowering $\left(73.51 \mathrm{~cm}^{2}\right)$ to start of flowering $\left(82.26 \mathrm{~cm}^{2}\right)$ and thereafter, it was decreased gradually at later stages i.e. early fruiting $\left(79.17 \mathrm{~cm}^{2}\right)$, peak fruiting $\left(73.15 \mathrm{~cm}^{2}\right)$ and late fruiting $\left(60.21 \mathrm{~cm}^{2}\right)$. Spacing had no significant effect on leaf area at pre-flowering and start of the flowering, but at later stages, widest spacing $(75 \times 90 \mathrm{~cm})$ exhibited significantly maximum leaf area at early fruiting $\left(82.44 \mathrm{~cm}^{2}\right)$, peak fruiting $\left(78.22 \mathrm{~cm}^{2}\right)$ and late and fruiting $\left(65.31 \mathrm{~cm}^{2}\right)$. Leaf area increased due to increased NPK levels with maximum values under 100:80:80 kg NPK ha-1 at all the phenological stages: pre-flowering $\left(78.99 \mathrm{~cm}^{2}\right)$, start of flowering $\left(90.97 \mathrm{~cm}^{2}\right)$, early fruiting $\left(88.47 \mathrm{~cm}^{2}\right)$, peak fruiting $\left(80.74 \mathrm{~cm}^{2}\right)$ and late fruiting $\left(67.22 \mathrm{~cm}^{2}\right)$. Spacing $\times$ NPK Interactions was significant only at peak fruiting and late fruiting stages with maximum leaf area (75.22 and $71.02 \mathrm{~cm}^{2}$, respectively) at $75 \times 90 \mathrm{~cm}+$ NPK @ 100:80:80 kg ha-1. These findings can be further helpful in leaf sclerophylly studies in cape gooseberry.
\end{abstract}

Keywords: Cape gooseberry, Leaf area, NPK, Phenological stage, Physalis peruviana L., Spacing

\section{INTRODUCTION}

Morphomertic monitoring of crops plants during the growing season becomes increasingly important in order to adjust the crop husbandry and to provide information for obtaining optimum yield. In growing crop canopies, foliar traits such as leaf area index and leaf mass per unit area are the important factors in leaf light harvesting capacity and photosynthetic potentials. Leaf area of crop is one of the most important parameter required in the estimation of several plant growth indices and various models for predicting crop growth and dry matter production, development rate, yield potential, radiation use efficiency (Centritto et al., 2000; Williams and Martinson, 2003), quantifying crop-weed competition, energy and water exchanges in the plant soil-atmosphere continuum, as they are associated with photosynthesis and evapo-transpiration (Guo and Sun, 2001). Leaves of the same canopy often show different rates of photosynthesis and transpiration, therefore, estimations of leaf area linked to physiological characteristics are essential to define the overall contribution of each canopy portion to fruit quality and yield (Serdar and Demirsoy, 2006; Ribeiro and Machado, 2007).

Apart from genetic potential of the crop, the growing environments have profound effects on crop development resulting in modified overall canopy structure and appearance. Altering the soil fertility by providing balanced nutrition as per the crop requirements is one of the easiest ways to boost up crop productivity. A reliable supply of nitrogen, phosphorus and potassium is crucial and especially significant for synthetic events within growing cells. Leaf expansion is particularly sensitive to nutrient supply (especially nitrogen, phosphorus and potassium), primarily to the needs of enlarging cells for synthesis of new materials and generation of turgor. Leaf area and vertical L profile influence the interception and utilization of solar radiation of crop and consequently, the dry matter production (Boote et al., 1998). Better correlation appeared between leaf areas and weights at the high nitrogen rate than at the low nitrogen rate (Miller et al., 1967). Since the interception in the supply of major nutrients even for a brief period is determined by pattern of crop growth and development which may 
produce less yield and poor quality and it cannot be corrected or altered at later stages of the crop growth even by supplying with heavier doses of major nutrients (Dwivedi et al., 2002). Further, spatial arrangement of a crop affects plant biomass allocation and yields. The interaction between vegetation surface and the atmosphere is substantially determined by the vegetation surface (Monteith and Unsworth, 1990), consequently the variation in canopy light availability is a result of foliage structural and canopy architectural characteristics (Maddonni et al., 2001). Plant leaf area is an important determinant of light interception and consequently of transpiration, photosynthesis (Goudriaan and Laar, 1994), and hence has a substantial influence plant productivity.

The cape gooseberry (Physalis peruviana L.; Family: Solanaceae) is a soft wooded, herbaceous crop has long been a minor fruit of the Andes and also been grown in California, South Africa, East Africa, India, New Zealand, Australia, and Great Britain, so far, now becoming popular in several countries like California, South Africa, New Zealand, Australia, East Africa, and tropical south America. Cape gooseberries are mainly cultivated for its delicious fruits that fetches very high price, for example, Europeans, often pay premium prices for the fruits, which are dipped in chocolate or used to decorate cakes and tortes (Ramadan and Morsel, 2003). Beside several well documented phytochemical values of this crop, the nutritional value of the fruits is excellent and comparable with any other major fruit crops of India. Although, it is a minor crop in India, but deserves special attention particularly due to wide adoptability, quick growing in nature, high productivity, non-perennial occupation of land, availability delicious fruit with pleasing acetic taste in lean period of time. According to Morton (1987), cape gooseberry is said to succeed wherever tomatoes can be grown. While for tomatoes and other major solanacious crops, there generally exists a lot of information and practical recommendations; the literature sources for cape gooseberry are very limited. Although, few studies have been carried out so far, but still there is lack of knowledge for various physiological traits, particularly variations in leaf area during growth and development of plant under varying growing conditions. This work aims to investigate the leaf area variation in during different phenological stages of cape gooseberry (Physalis peruviana) under varying plant spacing and fertility levels.

\section{MATERIALS AND METHODS}

Location and site characteristics: The study was conducted at Main Experimental Station of the Department of Horticulture, Narendra Deva University of Agriculture and Technology, Kumarganj, Faizabad (latitude $26^{\circ} 47^{\prime} \mathrm{N}$, longitude $85^{\circ} 12^{\prime} \mathrm{E}$ and $113 \mathrm{~m}$ elevation) during two consecutive cropping seasons
2004-05 and 2005-06. The location falls under Indo-Gangatic plains of Eastern Uttar Pradesh of India. This site is characterised by sub-humid and sub-tropical climate observing mean annual rainfall $1190 \mathrm{~mm}$, mainly received during July to September, however, the occasional showers during winter (October - mid February) and also in summer (April mid June) also not uncommon. The summer months are hot, dry and desiccating. The corresponding clay loam sodic soil had the following chemical properties: pH 8.56; EC $0.42 \mathrm{dSm}^{-1}$; organic carbon $0.35 \%$, available nitrogen $190.44 \mathrm{~kg} \mathrm{ha}^{-1} \%$, available phosphorus $17.86 \mathrm{~kg} \mathrm{ha}^{-1}$ and available potassium $229.34 \mathrm{~kg} \mathrm{ha}^{-1}$.

Plant material and treatments: Cape gooseberry genotype S-101 (Suttind Seeds Pvt. Ltd.) was used in this study for raising the seedlings for transplants. The treatment consisted of thee plant spacing $\left(\mathrm{S}_{1}-75 \times 60\right.$ $\mathrm{cm}, \mathrm{S}_{2}-75 \times 75 \mathrm{~cm}$ and $\left.\mathrm{S}_{3}-75 \times 90 \mathrm{~cm}\right)$ and four fertility (NPK) levels $\left(\mathrm{F}_{0}-\right.$ control - without NPK fertilizers, $F_{1}-60: 40: 40, \quad F_{2}-80: 60: 60$ and $F_{3}-$ 100:80:80 NPK kg ha ${ }^{-1}$ ). The experiment was laid out in Spit Plot Design with four replications, wherein main plot was assigned with plant spacing and levels of NPK in the sub-plots. Five phenological stages of plant were also considered as sub-sub plot treatment for obtaining statistical significance of phenological stages. The seedlings raised in semi-controlled polyhouse having uniform vigor and size were transplanted in evening hours in second week of August for both year's experiments. The size of individual plots was $9.0 \times 3.0 \mathrm{~m}$. The source for nitrogen, phosphorus and potassium fertilizers was ure, single super phosphate and murate of potash. One-third nitrogen and full amount of phosphorus and potassium were applied during last preparation of experimental soil. Remaining quantity of nitrogen was divided into two equal parts and top dressed at 45 and 75 days after transplanting. Other cultural operations were similar for all the treatments.

Data collection and analysis: Twenty fully expanded leaves were randomly selected from each treatment for measuring the leaf area at pre-flowering (30 DAT), starts of flowering (60 DAT), early fruiting (120 DAT), peak fruiting (180 DAT) and late fruiting (240 DAT). The leaf area of each leaf was recorded with the help of Leaf Area Meter (Delta Devices, Cambridge, UK) and the average values were expressed in $\mathrm{cm}^{2}$. Data collected during two consecutive cropping seasons were pooled and analyzed as per standard procedure as advocated by Panse and Sukhatme (1986) at $5 \%$ level of level of significance.

\section{RESULS AND DISCUSSION}

Data depicted in Fig. 1 revealed that the leaf area was significantly varied at different stages of plant. Among five stage of plant growth, there was significant 
Table 1. Effect of plant spacing on leaf area $\left(\mathrm{cm}^{2}\right)$ of cape gooseberry at different phenological stages .

\begin{tabular}{lcccccc}
\hline \multirow{2}{*}{ Spacing (S) } & \multicolumn{5}{c}{ Phenological stage } \\
\cline { 2 - 7 } & $\begin{array}{c}\text { Pre- flowering } \\
\text { (30 DAT) }\end{array}$ & $\begin{array}{c}\text { Start of } \\
\text { Flowering } \\
\text { (60 DAT) }\end{array}$ & $\begin{array}{c}\text { Early fruiting } \\
\text { (120 DAT) }\end{array}$ & $\begin{array}{c}\text { Peak fruiting } \\
\text { (180 DAT) }\end{array}$ & $\begin{array}{c}\text { Late fruiting } \\
\text { (240 DAT) }\end{array}$ & Mean \\
\hline $\mathrm{S}_{1}-75 \times 60 \mathrm{~cm}$ & 72.80 & 80.87 & 75.54 & 67.76 & 55.03 & 70.40 \\
$\mathrm{~S}_{2}-75 \times 75 \mathrm{~cm}$ & 73.78 & 82.39 & 79.45 & 73.34 & 60.31 & 73.85 \\
$\mathrm{~S}_{3}-75 \times 90 \mathrm{~cm}$ & 73.97 & 83.52 & 82.44 & 78.22 & 65.31 & 76.69 \\
$\mathrm{CD}_{(\mathrm{P}=0.05)} \mathrm{S}$ & $\mathrm{NS}$ & $\mathrm{NS}$ & 2.33 & 2.19 & 1.96 & - \\
\hline
\end{tabular}

Table 2. Effect of NPK levels on leaf area $\left(\mathrm{cm}^{2}\right)$ of cape gooseberry at different phenological stages.

\begin{tabular}{lcccccc}
\hline \multirow{2}{*}{ NPK Level (F) } & \multicolumn{5}{c}{ Phenological stage } \\
\cline { 2 - 7 } & $\begin{array}{c}\text { Pre- } \\
\text { flowering } \\
(\mathbf{3 0} \text { DAT) }\end{array}$ & $\begin{array}{c}\text { Start of } \\
\text { Flowering } \\
(\mathbf{6 0} \text { DAT) }\end{array}$ & $\begin{array}{c}\text { Early } \\
\text { fruiting } \\
(\mathbf{1 2 0} \text { DAT) }\end{array}$ & $\begin{array}{c}\text { Peak } \\
\text { fruiting } \\
(\mathbf{1 8 0} \text { DAT) }\end{array}$ & $\begin{array}{c}\text { Late } \\
\text { fruiting } \\
(\mathbf{2 4 0} \text { DAT) }\end{array}$ & Mean \\
\hline $\mathrm{F}_{0}$-control & 65.31 & 69.04 & 66.29 & 58.83 & 48.33 & 61.56 \\
$\mathrm{~F}_{1}-60: 40: 40 \mathrm{~kg} \mathrm{ha}^{-1}$ & 73.28 & 80.77 & 76.97 & 74.11 & 61.45 & 73.32 \\
$\mathrm{~F}_{2}-80: 60: 60 \mathrm{~kg} \mathrm{ha}^{-1}$ & 76.47 & 88.08 & 84.83 & 78.74 & 63.86 & 78.50 \\
$\mathrm{~F}_{3}-100: 80: 80 \mathrm{~kg} \mathrm{ha}^{-1}$ & 78.99 & 90.97 & 88.47 & 80.74 & 67.22 & 81.28 \\
$\mathrm{CD}_{(\mathrm{P}=0.05)}$ & 2.32 & 2.93 & 2.25 & 2.60 & 1.85 & - \\
\hline
\end{tabular}

increase in leaf area from pre-flowering to start of flowering stage, and thereafter gradual decrease in leaf area was noted with advancement of later stages of plant (early fruiting, peak fruiting and late fruiting stage). Maximum leaf area was measured at start of flowering (60 DAT) followed by early fruiting (120 DAT), peak fruiting (180 DAT) and pre-flowering (30 DAT). Among different phenological stages of plant, lowest leaf area was recorded at late fruiting (240 DAT). Reduced leaf area during later phonological stages might be attributed to the facts that strong competition for assimilate availability among developing leaves, flowers and fruits occurs with the advancement of phenological stages particularly after start of flowering which leads to the partitioning of the available metabolites in developing plant parts. Dalal et al. (2013) also noted seasonal variation in leaf area in kinnow mandarin that the spring flush leaves had the minimum values of leaf area as compared to rainy and winter fall flushes leaves, implying that spring season growth most serves as a sink to developing fruits.

Plant spacing had non-significant effect on leaf area measured at pre-flowering (30 DAT) and start of flowering (60 DAT), but at later stages of plant i.e. early fruiting (120 DAT), peak fruiting (180 DAT) and late fruiting (240 DAT), significant difference in leaf area was observed due to plant spacing treatments (Table 1). At all the phenological stages, maximum leaf area was recorded with widest plant spacing $(75 \times 90 \mathrm{~cm})$ flowed by medium spacing $(75 \times 75 \mathrm{~cm})$ and minimum with closest spacing $(75 \times 60 \mathrm{~cm})$. Camacaro, et al. (2004) and Sonkar et al. (2012) found that wider plant spacing increased leaf area in strawberry,while in an experiment under greenhouse conditions, Um et at. (1997) reported that planting density did not affect the leaf area in tomato. While increasing the plant populations per unit area, intra-plant competition becomes more important and light interception also varied with crop development; the planting pattern optimises the available natural and unnatural resources and row spacing become important in crop canopy structure (Andrade et al., 2002; Reta-Sanchez and Fowler, 2002; Sharratt and McWilliams, 2005). The state of development of the plant determines the pattern distribution of dry matter in different organs of the plant, and the leaf area growth determines the light interception pattern (Heuvelink and Marcelis, 1989). As strong competition between developing leaves and apical meristem influences plant growth, high assimilate availability under high light intensity conditions stimulates both meristem activity and leaf growth (Hussey, 1963a), but when plants are source-limited, young leaf growth is favoured at the expense of apical development; hence, continuous removal of young leaves counteracts this effect (Hussey, 1963b, Kinet, 1977). In cape gooseberry, vegetative growth and reproductive development proceed concomitantly during the 
Table 3. Interaction effect of plant spacing x NPK levels on leaf area at peak fruiting (180 DAT) in cape gooseberry

\begin{tabular}{lcccc}
\hline Spacing (S) & \multicolumn{4}{c}{ Leaf area $\left.\mathbf{c m}^{\mathbf{2}}\right)$ at peak Fruiting } \\
\cline { 2 - 5 } & $\mathbf{F}_{\mathbf{0}}$ & $\mathbf{F}_{\mathbf{1}}$ & $\mathbf{F}_{\mathbf{2}}$ & $\mathbf{F}_{\mathbf{3}}$ \\
\cline { 2 - 5 } & 50.84 & 57.34 & 61.37 & 63.74 \\
$\mathrm{~S}_{1}-75 \times 60 \mathrm{~cm}$ & 59.27 & 66.19 & 69.93 & 70.71 \\
$\mathrm{~S}_{2}-75 \times 75 \mathrm{~cm}$ & 66.39 & 74.45 & 74.83 & 75.22 \\
$\mathrm{~S}_{3}-75 \times 90 \mathrm{~cm}$ & & 4.53 & \\
$\mathrm{CD}_{(\mathrm{P}=0.05)} \mathrm{S} \times \mathrm{F}$ & & & & \\
\hline
\end{tabular}

Table 4. Interaction effect of plant spacing x NPK levels on leaf area at late fruiting (240 DAT) in cape gooseberry

\begin{tabular}{lcccc}
\hline Spacing (S) & \multicolumn{5}{c}{ Leaf area $\left(\mathbf{c m}^{2}\right)$ at Late fruiting } \\
\cline { 2 - 5 } & $\mathbf{F}_{\mathbf{0}}$ & $\mathbf{F}_{\mathbf{1}}$ & $\mathbf{F}_{\mathbf{2}}$ & $\mathbf{F}_{\mathbf{3}}$ \\
\cline { 2 - 6 } & 42.15 & 54.85 & 58.58 & 64.54 \\
\hline $\mathrm{S}_{1}-75 \times 60 \mathrm{~cm}$ & 48.50 & 62.02 & 64.61 & 66.10 \\
$\mathrm{~S}_{2}-75 \times 75 \mathrm{~cm}$ & 54.35 & 67.47 & 68.38 & 71.02 \\
$\mathrm{~S}_{3}-75 \times 90 \mathrm{~cm}$ & & & 3.20 & \\
$\mathrm{CD}_{(\mathrm{P}=0.05)} \mathrm{S} \times \mathrm{F}$ & \multicolumn{4}{c}{} \\
\hline
\end{tabular}

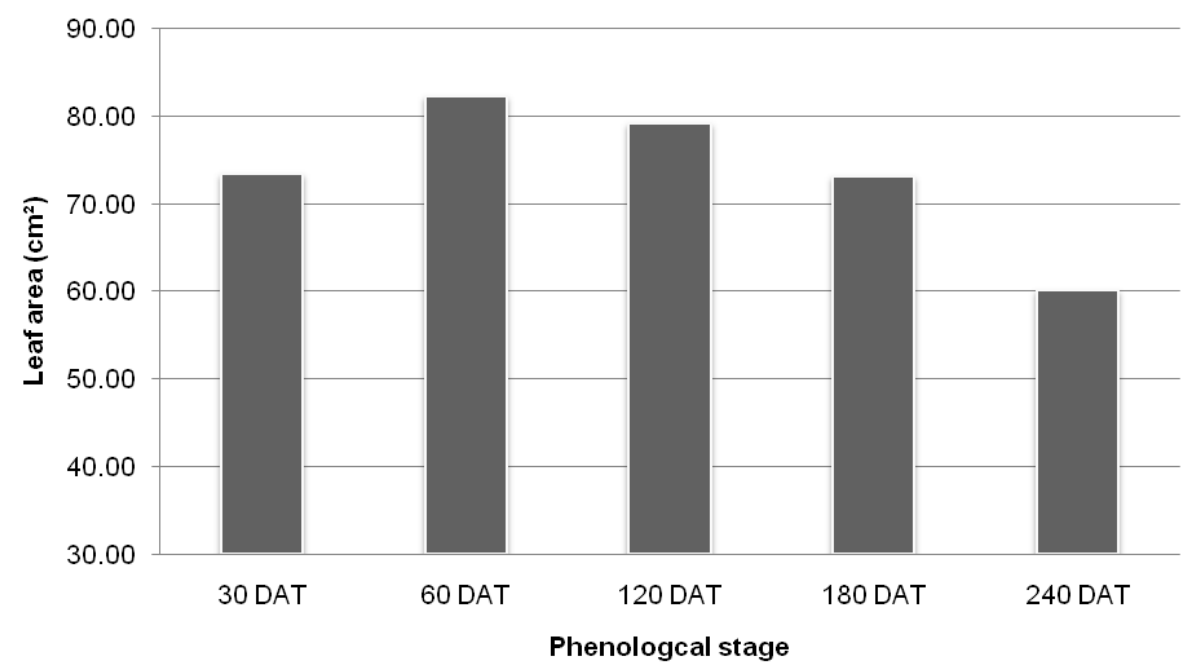

Fig. 1. Leaf area variation during different phenological stages of cape gooseberry. Bars with different letters within the same year differed significantly at $\mathrm{P}_{=0.05}$. DAT $=$ days after transplanting.

greater part of the plant life. Lower leaf area at later stages of plant was might be due to source-limited and low root activity with aging process.

Application of NPK fertilizers significantly increased leaf area in cape gooseberry at all stages of plant growth (pre-flowering, early fruiting, starts of flowering, peak fruiting and late fruiting stages) during both year's study (Table 2). Maximum leaf area was measured with the application of highest level of NPK (100:80:80 $\left.\mathrm{kg} \mathrm{ha}^{-1}\right)$ followed by 80:60:60 $\mathrm{kg} \mathrm{NPK} \mathrm{ha}^{-1}$ and $60: 40: 40 \mathrm{~kg} \mathrm{ha}^{-1}$ at all the five stages under study. Minimum leaf area was recorded in control (no NPK fertilizers) at all the phenological stages. Increase in leaf area with the application of $\mathrm{N}$,
$\mathrm{P}$ and $\mathrm{K}$ in alone or in combinations have been reported in tomato by researchers viz. N (Varia et al., 1998), $\mathrm{P}$ (Basirat et al., 2011), N and P (Regina and Robert, 1991), N, P and K (Baldissera, 2004; Adekiya and Agbede, 2009). In potato, low $P$ supply reduced total leaf area per plant (Balemi, 2009). Shabani et al., (2012) reported increased leaf area in salinity stressed cherry tomato with increased $\mathrm{K}^{+}$concentration. It is well evident from the available literatures that $\mathrm{N}, \mathrm{P}$ and $\mathrm{K}$ are required in large quantity by the plant, where nitrogen is the most limiting nutrient to crop production (Pionke et al., 1990). Nitrogen mediates leaf expansion via increase in cell number, rather than cell size, maintenance of leaf turgor and enhancing the availabil- 
ity of assimilates (Sivasankar et al., 1993). Phosphorus helps in better utilization of water and other nutrients in the soil and promotes a sturdy growth of stem and healthy foliage (Nelson, 1978). Potassium plays key role in metabolic and transport processes, charge balance, and generation of turgor pressure (Dorais et al., 2001). An increased $\mathrm{K}$ concentration in root can increase photosynthetic efficiency possibly by increasing the number of chloroplast per cell per leaf and consequently leaf area (Possingham, 1980. Lopez and Sattii (1996) observed a great decrease in photosynthetic activity with decreasing supply of $\mathrm{K}$ to the roots. Furthermore, $\mathrm{K}$ is required for activity of some enzymes (Shafeek, et al., 2005). Beneficial effects of NPK on leaf area in our study were attributed to increased nutrient availability and root growth leading to enhanced uptake of mineral nutrients and water. Beaton

observed that biweekly application of 20N-4.3P-8.3K fertilizers enhanced leaf area and runner production in strawberry.

Interaction effect of plant spacing and NPK levels was significant $(\mathrm{P}=0.05)$ with respect to leaf area at peak fruiting and late fruiting (180 DAT and 240 DAT, respectively). At peak fruiting, maximum leaf area was recorded with the treatment combination of widest spacing $(75 \times 90 \mathrm{~cm})+$ highest level of NPK $\left(100: 80: 80 \mathrm{~kg} \mathrm{ha}^{-1}\right)$ (Table 3). At late fruiting, leaf area was also highest with the treatment combination of widest spacing $(75 \times 90 \mathrm{~cm})+$ highest level of NPK (100:80:80 kg ha-1) (Table 4). Minimum leaf area at peak fruiting and late fruiting in both year experiments was recorded at closest spacing $(75 \times 60$ $\mathrm{cm}$ ) without NPK fertilizers (Tables 3 and 4). The phonological stages of peak fruiting and late fruiting were the most critical period of the fruit growth and development in the plant that had high demands of the plant nutrients (nitrogen, phosphorus and potassium) required for growth and development. Higher leaf area under wider plant spacing + higher levels of applied NPK fertilizers might be attributed to limited possibility of plant competition for these nutrients while close plant spacing + lover levels of applied NPK fertilizers had limited supply of nutrients resulting in lower leaf area in the plants.

\section{Conclusion}

In present study, leaf area increased from perflowering to start of flowering, and thereafter it was gradually decreased at each later phenological stage. Plant spacing did not affected the leaf area during early stages (pre-flowering and start of flowering) but at later stages (early fruiting, peak fruiting, and late fruiting), wide-space planting resulted higher leaf area. The NPK application increased leaf area at all the phenological stages with maximum value at 100:80:80 kg NPK ha ${ }^{-1}$. Spacing $x$ NPK interactions were significant only at later stages (peak fruiting and late fruiting stages) showing maximum leaf area at $75 \times 90 \mathrm{~cm}$ with NPK@100:80:80 kg ha ${ }^{-1}$. Leaf area variations at different phenological stages observed in present study can be further helpful in leaf sclerophylly studies in cape gooseberry.

\section{REFERENCES}

Adekiya A.O. and Agbede, T.M. (2009). Growth and yield of tomato (Lycopersicon esculentum Mill) as influenced by poultry manure and NPK fertilizer. Emir. J. Food Agric., 21(1): 10-20

Andrade, F.H., Calvino, P., Cirilo A. and Barbieri, P. (2002). Yield responses to narrow rows depend on increased radiation interception. Agron J., 94: 975-980

Baldissera, C.T., Frak, E., Carvalho, P.C.F. and Louarn, G. (2004). Plant development controls leaf area expansion in alfalfa plants competing for light. HortSci., 39(1): 4954

Balemi, T. (2009). Effect of phosphorus nutrition on growth of potato genotypes with contrasting phosphorus efficiency. African Crop Sci. J., 17(4). 199-212

Basirat, M., Malboobi, M.A., Mousavi, A., Asgharzadeh, A. and S. Samavat, (2011). Effects of phosphorous supply on growth, phosphate distribution and expression of transporter genes in tomato plants. Austral. J. Crop Sci., 5(5):537-543

Beaton, G.W. (1987). Effect of fertilizer, paclobutraol and chloremquat on strawberry. J. Amer. Soci. Hort. Sci., 112(2): 241-246

Boote, K.J., Jones, J.W., and Hoogenboom, G. (1998). Simulation of crop growth CROPGRO model. In: Peart R.M. and Curry R. (Eds.) Agricultural Systems Modeling and Simulation, Marcel Dekker Inc., New York, USA.

Camacaro, D., Camacaro, M.E.P., Hadley, G.J. P., Dennett, M.D. Battey, N.H. and Carew, J.G. (2004). Effect of plant density and initial crown size on growth, development and yield in strawberry cultivars Elsanta and Bolero. J. Hort. Sci. Biotech., 79(5): 739-746.

Centritto M., Loreto F., Massacci A., Pietrini F., Villani M.C. and Zacchine M. (2000). Improved growth and water use efficiency of cherry saplings under reduced light intensity, Ecol. Res., 15(4) 385-392.

Dalal, R.P.S., Beniwal, B.S. and Sehrawat, S.K. (2013). Seasonal variation in growth, leaf physiology and fruit development in kinnow, a mandarin hybrid. J. Plant Studies, 2(1): 72-77.

Dorais, M.A., Papadopoulos, and Gosselim, A. (2001). Greenhouse tomato fruit quality, Hort. Rev., 26: 239319.

Dwivedi, Y.C., Kushwah S. and Sengupta S.K. (2002). Studies on nitrogen, phosphorus and potash requirement of dolichos bean. JNKVV Res. J., 36(1-2):47-50.

Goudriaan, J. and Laar, H.H.V. (1994). Modeling Potential Crop Growth processes. Kluwer Academic Publishers, Dordrecht, The Netherlands.

Guo, D.P. and Sun, Y.Z. (2001). Estimation of leaf area of stem lettuce (Lactuca sativa var. angustana) from linear measurements. Indian J. Agric. Sci., 71(7): 483-486.

Hussey, G. (1963a). Growth and development in young tomato. I. The effect of temperature and light intensity on growth of the shoot apex and leaf primordia. J. Exptl. 
Biol., 14: 316-325.

Hussey, G. (1963b). Growth and development in growing tomato. II. The effect of defoliation on the development of the shoot apex. J. Exptl. Biol., 14: 326-331

Heuvelink, E. and Marcelis, L.F.M. (1989). Dry matter distribution in tomato and cucumber. Acta Hortic., 260, 149-157

Kinet, JM. (1977). Effect of defoliation and growth substances on the development of inflorescence on tomato. Scientia Hort., 6: 27-35

Lopez, M.V. and Sattii, S.M.E. (1996). Calcium and potassium enhanced growth and yield of tomato under stress. Plant Sci., 114: 19-27

Maddonni, G.A., Otegui, M.E. and Cirilo, A.G. (2001). Plant population density, row spacing and hybrid effects on maize canopy architecture and light attenuation. Field Crop Res., 71: 183-193

Miller, R.J., Langdale, G.W. and Myhre, D.L. (1967). Leaf area indices and nitrogen uptake of flue-cured tobacco as affected by plant density and nitrogen rate. Agron. J., 59(5): 409-412

Monteith, J.L. and Unsworth, M.H. (1990). Principles of Environmental Physics. Edward Arnold, London.

Morton, F.J. (1987). Cape Gooseberry, In: Morton, F.J. (ed.) Fruits of warm climates. University of Miami, Miami, USA, pp. 430-434

Nelson, W.L. (1978). Phosphorus and moisture. In: Phosphorus for Agriculture. Phosphate and Potash Institute, Atlanta, GA.

Panse, V.G. and Sukhatme, P.V. (1986). Statistical Methods for Agricultural Workers, Forth Edn. ICAR Publications, New Delhi, India.

Pionke, H.B., Sharma, M.L. and Hirschberg, K.J. (1990). Impact of irrigated horticulture on nitrate concentration in ground water. Agric. Ecosys. Environ., 32: 199-122

Possingham, J.V. (1980). Plastid replication and development in life cycle of higher plants. Ann. Rev. Plant Physiol., 31: 113-129

Ramadan M.F. and Morsel, J.T. (2003). Oil goldenberry (Physalis peruviana L.). J. Agric. Food Chem., 51: 969974

Regina, R.M. and Robert, J.D (1991). Nitrogen, phosphorus, and potassium fertility regimes affect tomato transplant growth. HortSci., 26(2):141-142

Reta-Sanchez, D.G. and Fowler, J.L. (2002). Canopy light environment and yield of narrow-row cotton as affected by canopy architecture. Agron. J., 94: 1317-1323

Ribeiro, R.V. and Machado, E.C. (2007). Some aspects of citrus ecophysiology in subtropical climates: re-visiting photosynthesis under natural conditions, Brazilian. J. Plant Physiol., 19: 393-411

Serdar, U. and Demirsoy, H. (2006). Non-destructive leaf area estimation in chestnut, Scientia Hort., 108: 227230

Shabani, E., Tabatabaei, S.J., Bolandnazar, S. and Ghasemi, K. (2012). Vegetative growth and nutrient uptake of salinity stressed cherry tomato in different calcium and potassium level. Intl. Res. J. Applied Basic Sci., 3 (9):1845-1853

Shafeek, M.R., El-Zeiny, A.H. and Ahmed, M.E. (2005). Effect of phosphate and potassium fertilizer on growth, yield and seed composition of pea plants in new reclaimed soils. Asian J. Plant Sci., 4: 608-612

Sharratt, B.S and McWilliams, D.A. (2005). Microclimatic and rooting characteristics of narrow-row versus conventional-row corn. Agron. J., 97: 1129-1135

Sivasankar, A., Bansal, K.C. and Abrol, Y.P. (1993). Nitrogen in relation to leaf area development and photosynthesis. Proc. Indian Natl. Sci. Acad., 59(4-5): 235-244.

Sonkar, P., Ram, R.B. and Meena, M.L. (2012). Effect of various mulch materials and spacing on growth, yield and quality of strawberry. HortFlora Res. Spectrum, 1 (4): $323-327$

Um, Y.C. Park, D.K., Lee, J.K., Cheong, J.W. and Kang, K.W. (1997). Effect of planting density and side shoot allowing on growth and seasonal yield in green house grown tomato. RDA J. Hort. Sci., 39(2): 21-26

Varia, C.S. Hochmuth, G.J., Cornell, J.A. and Olson, S.M. (1998). Nitrogen fertilization of Florida-grown tomato transplants: Seasonal variation in greenhouse and field performance. HortScience, 33(2): 251-254

Williams, L. and Martinson, T.E. (2003). Nondestructive leaf area estimation of 'Niagara' and 'DeChaunac' grapevines. Scientia Hort., 98: 493-498 